\title{
Pengembangan Media Pembelajaran Matematika Menggunakan Mit App Inventor di SMKN 2 Wajo
}

\author{
Fitri $^{1}$, Mustari S. Lamada ${ }^{2}$ Zulhajji $^{3}$ \\ 1,2,3 Universitas Negeri Makassar \\ fitriabs72@gmail.com \\ ${ }^{2}$ mustarilamadalg mail.com \\ ${ }^{3}$ ajimuda@yahoo.co.id
}

\begin{abstract}
Abstrak - Penelitian ini adalah penelitian pengembangan yang bertujuan untuk a) mengetahui media pembelajaran matematika menggunakan MIT App Inventor pada materi trigonometri di SMKN 2 Wajo valid digunakan, b) mengetahui media pembelajaran matematika menggunakan MIT App Inventor pada materi trigonometri di SMKN 2 Wajo praktis digunakan, dan untuk c) mengetahui media pembelajaran matematika menggunakan MIT App Inventor pada materi trigonometri di SMKN 2 Wajo efektif digunakan. Model pengembangan yang digunakan dalam penelitian ini adalah model Thiagarajan (1974) yaitu model 4D yaitu pendefinisian (define), perancangan (design), pengembangan (development) dan penyebaran (dissemination). Pengembangan ini tidak sampai pada tahap penyebaran (dissemination) karena adanya beberapa keterbatasan peneliti. Media divalidasi oleh 6 orang ahli dan dinilai oleh 2 orang guru serta pengujian dilakukan dengan 2 tahap uji coba. Teknik analisis yang digunakan adalah teknik analisis kuantitatif. Hasil penelitian ini adalah a) berdasarkan hasil penelitian yang diperoleh dari uji validasi ahli materi didapatkan kualifikasi sangat valid dan ahli desain dengan kualifikasi sangat valid, b) hasil uji coba peserta didik kelompok kecil didapatkan kualifikasi sangat praktis dan uji coba kelompok besar didapatkan kualifikasi sangat praktis, c) hasil penilaian keefektifan media oleh guru didapatkan kualifikasi sangat efektif dan hasil penilaian peserta didik didapatkan dengan kualifikasi sangat efektif.
\end{abstract}

Kata Kunci: Pengembangan, Media, Matematika, MIT App Inventor

\section{PENDAhuluan}

Perkembangan teknologi informasi yang semakin pesat di era globalisasi saat ini tidak bisa lagi dihindari pengaruhnya terhadap dunia pendidikan. Tuntutan global menuntut dunia pendidikan untuk selalu menyesuaikan perkembangan teknologi dalam usaha peningkatan mutu pendidikan, terutama penyesuaian penggunaan teknologi informasi dan komunikasi bagi dunia pendidikan khususnya dalam proses pembelajaran.

Dunia pendidikan tidak terlepas dari proses pembelajaran yang meliputi guru, peserta didik, dan lingkungan pembelajaran yang saling mempengaruhi satu sama lain dalam rangka tercapainya tujuan pembelajaran. Media merupakan salah satu faktor penunjang tercapainya tujuan pembelajaran. Hal ini berkaitan dengan penggunaan media yang tepat dan bervariasi dalam proses pembelajaran dapat meningkatkan motivasi belajar dan dapat mengurangi sikap pasif peserta didik (Hardianto, 2005).

Media pembelajaran berperan penting dalam proses belajar mengajar sehingga dapat meningkatkan kualitas pendidikan. Selain itu, penggunaan media pembelajaran dalam proses pembelajaran matematika dapat membangkitkan motivasi dan minat belajar siswa secara mandiri. Seiring berkembangnya teknologi, media pembelajaran perlu mengikuti perkembangan yang ada dengan memanfaatkan teknologi sehingga tercapainya tujuan pembelajaran untuk mengefektifitaskan proses komunikasi pembelajaran (Mulyastuti, 2017).

Perkembangan teknologi mobile saat ini begitu pesat, perangkat mobile yang saat ini sudah umum digunakan adalah smartphone. Hampir $90 \%$ peserta didik pasti sudah mempunyai satu smartphone atau bahkan ada yang mempunyai lebih dari satu smartphone. Semakin banyaknya peserta didik yang memiliki dan menggunakan perangkat mobile maka semakin besar pula peluang penggunaan perangkat teknologi dalam dunia pendidikan.

Berdasarkan observasi yang dilakukan di kelas X RPL A dengan total 29 peserta didik, masing-masing sudah memiliki smartphone android. Di SMK Negeri 2 Wajo peserta didik diizinkan membawa smartphone, namun dalam pemanfaatannya sebagai media pembelajaran belum maksimal. Para peserta didik masih banyak yang menggunakan laptop atau bahkan masih ada yang menggunakan buku manual untuk menunjang pembelajaran di sekolah. Penggunaan laptop sebagai media pembelajaran cukup menyulitkan peserta didik karena berat untuk dibawa serta terkesan repot. Guru pun terkadang menggunakan media pembelajaran berupa power point. Namun, karena kurangnya fasilitas akibatnya guru lebih sering menggunakan metode konvensional dalam mengajar.

Melihat potensi ini, pengembangan media pembelajaran dengan memanfaatkan smartphone berplatform android sangat bermanfaat. Alasannya karena operating system android menjelma menjadi sebuah sistem yang paling banyak digunakan pada smartphone. Selain lebih praktis dan simpel, sudah banyak smartphone android yang harganya terjangkau dengan kisaran harga 1 juta rupiah. Dengan pembelajaran melalui media smartphone akan lebih praktis dilakukan dimana saja dan kapan saja sehingga dapat membuat peserta didik lebih mudah dalam mempelajari materi yang kurang dikuasai.

Berdasarkan penjelasan dan permasalahan diatas, perlu adanya pengembangan media pembelajaran matematika berbasis android menggunakan MIT App Inventor untuk menjadikan android lebih tepat guna dan memberikan kemudahan kepada peserta didik untuk belajar dimanapun dan kapanpun. Hasil penelitian ini diharapkan diperoleh media pembelajaran matematika berbasis android yang valid, praktis dan efektif.

\section{METODE PENELITIAN}

Model penelitian pengembangan yang digunakan dalam penelitian ini mengacu pada model 4D (four-D model) yang dikembangkan Thiagarajan dalam Mulyadi (2017). Adapun tahapan model pengembangan 4D meliputi tahap pendefinisian (define), tahap perancangan (design), tahap pengembangan (develop) dan tahap penyebaran (disseminate). Namun pada tahap dissemination tidak dilakukan peneliti karena adanya beberapa keterbatasan. 
Subjek ahli atau validator terdiri dari 2 validator instrumen dan 2 validator ahli media yang merupakan dosen di Fakultas Teknik Universitas Negeri Makassar, sedangkan 2 validator ahli materi merupakan guru matematika di SMK Negeri 2 Wajo. Subjek uji coba oleh guru terdiri dari 2 orang guru matematika dari SMK Negeri 2 Wajo. Sedangkan subjek uji coba kelompok kecil melibatkan 5 orang peserta didik dan kelompok besar terdiri dari 24 peserta didik kelas XI RPL A SMK Negeri 2 Wajo.

Instrumen merupakan alat yang digunakan dalam pengambilan data. Data yang dihasilkan akan akurat jika instrumen yang digunakan oleh peneliti telah dinyatakan valid, oleh karena itu diperlukan pemilihan instrumen yang tepat dalam penelitian dan pengembangan ini. Instrumen yang akan digunakan dalam pengembangan media pembelajaran ini adalah sebagai berikut:

\section{A. Wawancara}

Wawancara yang digunakan dalam penelitian ini dengan mengajukan pertanyaan terstruktur karena peneliti menggunakan pedoman wawancara yang disusun secara sistematis dan lengkap untuk mengumpulkan data yang dicari.

B. Dokumentasi

Dokumentasi digunakan untuk mengumpulkan data kemudian ditelaah. Dokumentasi yang digunakan dalam penelitian ini yaitu silabus, RPP dan lainnya.

C. Angket

Metode pengumpulan data yang digunakan dalam penelitian ini adalah metode angket atau kuesioner. Angket dipakai saat validasi serta uji coba media pembelajaran yang selesai dikembangkan.

Untuk menunjukkan tingkat valid suatu instrumen dapat diukur dari validitas. Instrumen yang memiliki validitas tinggi dikatakan valid untuk digunakan, sehingga dapat mengukur tentang apa yang seharusnya diukur. Validasi instrumen bertujuan untuk menilai kelayakan instrumen sebelum digunakan dalam penelitian agar data penelitian yang dihasilkan valid. Validasi ini dilakukan oleh dua orang dosen ahli. Hasil validasi instrumen oleh para ahli dapat dilihat pada tabel berikut:

\begin{tabular}{|c|c|c|c|c|c|}
\hline \multirow{2}{*}{$\begin{array}{c}\text { Jenis } \\
\text { Instrument }\end{array}$} & \multicolumn{2}{|c|}{ Validator } & \multirow{2}{*}{$\begin{array}{l}\text { Rata- } \\
\text { Rata }\end{array}$} & \multirow{2}{*}{ Persentase } & \multirow{2}{*}{ Kategori } \\
\hline & 1 & 2 & & & \\
\hline Ahli Media & 58 & 58 & 58 & $96.7 \%$ & $\begin{array}{l}\text { Sangat } \\
\text { Valid }\end{array}$ \\
\hline Ahli Materi & 58 & 59 & 58.5 & $97.5 \%$ & $\begin{array}{c}\text { Sangat } \\
\text { Valid }\end{array}$ \\
\hline $\begin{array}{l}\text { Kepraktisan } \\
\text { Media } \\
\end{array}$ & 58 & 58 & 58 & $96.7 \%$ & $\begin{array}{c}\text { Sangat } \\
\text { Valid }\end{array}$ \\
\hline $\begin{array}{l}\text { Keefektifan } \\
\text { Media }\end{array}$ & 58 & 59 & 58.5 & $97.5 \%$ & $\begin{array}{l}\text { Sangat } \\
\text { Valid }\end{array}$ \\
\hline
\end{tabular}

Sumber : Hasil olah data, 2020

Teknik analisis data yang digunakan peneliti untuk menganalisis data yang terkumpul dari angket adalah analisis kuantitatif. Analisis data kuantitatif digunakan untuk menganalisis data yang terkumpul dari angket yang menggambarkan apakah media pembelajaran yang telah dikembangkan memenuhi ketiga aspek kualitas, yaitu valid, praktis, dan efektif.

Pertanyaan dalam instrumen disesuaikan dengan media yang dikembangkan. Skor yang diperoleh dari angket dianalisis menggunakan Skala Likert yang terdiri dari beberapa kategori sebagai berikut:
Tabel 2. Ketentuan pemberian skor

\begin{tabular}{|c|c|}
\hline Skor & Respon \\
\hline 5 & Sangat Setuju \\
\hline 4 & Setuju \\
\hline 3 & Kurang Setuju \\
\hline 2 & Tidak Setuju \\
\hline 1 & Sangat Tidak Setuju \\
\hline
\end{tabular}

Analisis data dari angket diperoleh berupa skor dilakukan dengan menggunakan Persentase dari Suharsimi Arikunto (2010) yaitu :

$$
P=\frac{\sum x}{\sum x i} \times 100 \%
$$

Keterangan:

$\mathrm{P}=$ Persentase

$\sum x=$ Jumlah keseluruhan jawaban dalam seluruh item

$\sum x i=$ Jumlah keseluruhan nilai ideal dalam seluruh item

\section{A. Analisis Data Kevalidan Media}

Analisis data dari angket diperoleh berdasarkan tanggapan ahli materi dan ahli media. Adapun kriteria kevalidan yang digunakan disajikan pada tabel berikut :

Tabel 3. Kriteria Kevalidan

\begin{tabular}{|c|c|}
\hline Tingkat Pencapaian $(\boldsymbol{\%})$ & Keterangan \\
\hline$>80-100$ & Sangat Valid \\
\hline$>60-80$ & Valid \\
\hline$>40-60$ & Cukup Valid \\
\hline$>20-40$ & Kurang Valid \\
\hline $0-20$ & Tidak Valid \\
\hline
\end{tabular}

Sumber: (Arikunto, 2008) dengan modifikasi

B. Analisis Data Kpraktisan Media

Analisis data dari angket diperoleh berdasarkan tanggapan peserta didik. Kriteria kepraktisan yang digunakan dalam kepraktisan media disajikan pada tabel berikut :

Tabel 4. Kriteria Kepraktisan

\begin{tabular}{|c|c|}
\hline Tingkat Pencapaian (\%) & Kualifikasi \\
\hline$>80-100$ & Sangat Praktis \\
\hline$>60-80$ & Praktis \\
\hline$>40-60$ & Cukup Praktis \\
\hline$>20-40$ & Kurang Praktis \\
\hline $0-20$ & Tidak Praktis \\
\hline
\end{tabular}

Sumber: (Arikunto, 2008) dengan modifikasi

\section{Analisis Data Keefektifan Media}

Analisis data dari angket diperoleh berdasarkan tanggapan peserta didik dan guru. Kriteria keefektifan yang digunakan dalam keefektifan media disajikan pada tabel berikut:

Tabel 5. Kriteria Keefektifan

\begin{tabular}{|c|c|}
\hline Tingkat Pencapaian (\%) & Kualifikasi \\
\hline$>80-100$ & Sangat Efektif \\
\hline$>60-80$ & Efektif \\
\hline$>40-60$ & Cukup Efektif \\
\hline$>20-40$ & Kurang Efektif \\
\hline $0-20$ & Tidak Efektif \\
\hline
\end{tabular}

Sumber: (Arikunto, 2008) dengan modifikasi 


\section{III.HASIL PENELITIAN}

Hasil penelitian yang diperoleh adalah sebegai berikut: A. Validasi Ahli Materi

Validasi ahli materi dilakukan oleh 2 validator yang merupakan guru matematika di SMK Negeri 2 Wajo. Berdasarkan hasil validasi materi media oleh kedua ahli materi didapatkan total skor 255 dengan persentase $98.08 \%$ dengan kategori sangat valid. Sehingga dapat disimpulkan bahwa media sangat valid dan sudah layak digunakan sebagai media pembelajaran.

\section{B. Validasi Ahli Media}

Validasi ahli media dilakukan oleh 2 validator yang merupakan dosen di Fakultas Teknik Universitas Negeri Makassar. Berdasarkan hasil validasi media media oleh kedua ahli materi didapatkan total skor 272 dengan persentase $97.14 \%$ dengan kategori sangat valid. Sehingga dapat disimpulkan bahwa media sangat valid dan sudah layak digunakan sebagai media pembelajaran. Kelayakan tersebut merupakan bentuk produk yang benar-benar dinyatakan valid pada ahli media dan dapat melanjutkan ke pengguna atau peserta didik untuk diuji cobakan.

C. Kepraktisan Media

1. Uji Kelompok Kecil

Uji coba kelompok kecil yang dilakukan kepada 5 orang peserta didik kelas XI RPL A SMK Negeri 2 Wajo. Berdasarkan hasil uji coba kelompok kecil didapatkan total skor 431 dengan persentase $86.2 \%$ dengan kategori sangat praktis. Sehingga dapat disimpulkan bahwa media sangat praktis digunakan sebagai media pembelajaran.

2. Uji Kelompok Besar

Uji coba kelompok besar yang dilakukan kepada 24 orang peserta didik kelas XI RPL A SMK Negeri 2 Wajo. Berdasarkan hasil uji coba kelompok kecil didapatkan total skor 2141 dengan persentase $89.21 \%$ dengan kategori sangat praktis. Sehingga dapat disimpulkan bahwa media sangat praktis digunakan sebagai media pembelajaran.

\section{Keefektifan Media}

1. Penilaian Guru

Penilaian keefektifan media dilakukan kepada 2 orang guru matematika SMK Negeri 2 Wajo. Berdasarkan hasil penilaian didapatkan total skor 75 dengan persentase $93.75 \%$ dengan kategori sangat efektif. Sehingga dapat disimpulkan bahwa media sangat efektif digunakan sebagai media pembelajaran.

2. Penilaian Peserta Didik

Penilaian keefektifan media dilakukan kepada 29 orang peserta didik kelas XI RPL A SMK Negeri 2 Wajo. Berdasarkan hasil penilaian didapatkan total skor 971 dengan persentase $83.71 \%$ dengan kategori sangat efektif. Sehingga dapat disimpulkan bahwa media sangat efektif digunakan sebagai media pembelajaran.

\section{KESIMPULAN}

Berdasarkan hasil penelitian yang telah diuraikan serta melihat rumusan masalah yang ada, maka dapat disimpulkan bahwa:

1. Tingkat kevalidan media pembelajaran yang dikembangkan diperoleh berdasarkan hasil validasi para ahli. Pada hasil validasi ahli materi, media mendapatkan persentase validitas sebesar $98.08 \%$ dengan kategori sangat valid. Pada hasil validasi ahli media, media mendapatkan persentase validitas sebesar 97.14\% dengan kategori sangat valid. Sehingga, media pembelajaran matematika menggunakan MIT App Inventor ini memenuhi kategori sangat valid dan layak untuk digunakan sebagai media pembelajaran.

2. Tingkat kepraktisan media pembelajaran yang dikembangkan diperoleh berdasarkan hasil tanggapan peserta didik. Pada uji coba kelompok kecil diperoleh persentase sebesar 86.2\% dengan kriteria sangat praktis, dan uji coba kelompok besar diperoleh persentase sebesar $89.21 \%$ dengan kriteria sangat praktis. Sehingga dapat disimpulkan bahwa media pembelajaran matematika menggunakan MIT App Inventor sangat praktis untuk digunakan sebagai media pembelajaran.

3. Tingkat keefektifan media pembelajaran yang dikembangkan diperoleh berdasarkan hasil tanggapan peserta didik dan juga guru. Pada penilaian keefektifan media yang dinilai oleh guru diperoleh persentase $93.75 \%$ dengan kategori sangat efektif, dan penilaian keefektifan media yang dinilai oleh peserta didik diperoleh persentase $83.71 \%$ dengan kategori sangat efektif. Sehingga dapat disimpulkan bahwa media pembelajaran matematika menggunakan MIT App Inventor sangat efektif untuk digunakan sebagai media pembelajaran.

\section{DAFTAR PUSTAKA}

[1] Abdulloh, M. R. (2018). Pengembangan Aplikasi Android Untuk Keterampilan Menyimak Bahasa Prancis Siswa Kelas XI SMA Negeri 4 Purwokerto. Skripsi. Yogyakarta: Fakultas Bahasa dan Seni Universitas Negeri Yogyakarta.

[2] Amir, Z., \& Risnawati. (2016). Psikologi Pembelajaran Matematika. Yogyakarta: Aswaja Pressindo

[3] Arikunto, S. (2010). Prosedur Penelitian. Jakarta: Rineka Cipta

[4] Arikunto, S. , dkk. (2008). Prosedur Tindakan Kelas. Jakarta: PT Bumi Aksara

[5] Arsyad, A.(2014). Media Pembelajaran. Jakarta: PT Rajagrafindo Persada.

[6] Asyhari, A., \& Silvia, H. (2016). Pengembangan Media Pembelajaran Berupa Buletin Dalam Bentuk Buku Saku Untuk Pembelajran Ipa Terpadu. Jurnal Ilmiah Pendidikan Fisika Al-Biruni, 5(1), 1-13.

[7] Axel, R.D., Najoan, X., \& Sugiarso, B.A. (2017). Rancang Bangun Aplikasi Berbasis Android Untuk Informasi Kegiatan dan Pelayanan Gereja. E-Journal Teknik Elektro dan Komputer, 6(1).

[8] Fajrina, A. E. (2017). Pengembangan Mobile Encyclopedia Berbasis Android Sebagai Media Pembelajaran Mandiri Materi Pengantar Dan Referensi Baca Mata Pelajaran Gambar Konstruksi Bangunan 1 Smk Teknik Bangunan. Skripsi. Yogyakarta: Fakultas Teknik Universitas Negeri Yogyakarta.

[9] Falahudin, I. (2014). Pemanfaatan Media Dalam Pembelajaran. Jurnal Lingkar Widyaiswara, 1(4), 104-117.

[10] Giaudheen, F.P., \& Deepa, B. (2016). The Yummy Marshmallow - Android 6.0 Versions. International Journal of trend in research and development. 3(2).

[11] Hamzah, N. L. (2011). Teknologi Komunikasi \& Informasi Pembelajaran. Jakarta: PT. Bumi Aksara.

[12] Hanafi. (2017). Konsep Penelitian R\&D Dalam Bidang Pendidikan. Saintifika Islamica: Jurnal Kajian Keislaman. 4(2)

[13] Handayani, R. D. (2014). Pengembangan Bahan Ajar Elektronik Berbasis Mobile-Learning Pada Mata Kuliah Optik di FKIP UNIVERSITAS JEMBER. Jurnal Ta'dib, 17(1)

[14] Halim. A. (2012). Matematika: Hakikat dan logika. Yogyakarta: Ar-ruzz Media

[15] Hardesty, L. (2010). The MIT roots of Google's new software. MIT News Office. Diakses 15 februari 2020

[16] Hardianto, D. (2005). Media Pendidikan Sebagai Sarana Pembelajaran Efektif. Majalah Ilmiah Pembelajaran, 1(1), 95-104.

[17] Hendriani, E. (2019). Upaya Meningkatkan Hasil Belajar Siswa Dengan Project Based Learning Melalui Penugasan 
Membuat Vlog Materi Trigonometri. Jurnal On Education, 02(01).

[18] Kossasy, S. O. (2019). Mengulas Model-Model Pengembangan Pembelajaran Dan Perangkat Pembelajaran. Jurnal PPkn \& Hukum, 14(1), 152-173.

[19] Kusnandi, C \& Sutjipto, B. (2013). Media Pembelajaran Manual dan Digital. Bogor: Ghalia Indonesia

[20] Kusumadewi, W. Adi P. (2016). Pengembangan Media Pembelajaran Berbasis Simulasi Pada Mata Pelajaran Perkaitan Komputer Untuk Siswa Kelas X Di Smk Negeri 3 Surabaya. It-Edu, 1(01), 103-110.

[21] Leuw, J. E. F., Andjarwirawan, J., \& Wibowo, A. (2013). Pembuatan Aplikasi Pembelajaran Matematika Untuk Android Mobile Dengan Komunikasi Device-Server. Jurnal Infra., 1(2).

[22] Maimunah, M. (2016). Metode Penggunaan Media Pembelajaran. Al-Afkar: Jurnal Keislaman \& Peradaban, 5(1), 1-24.

[23] Masykur, R., Nofrizal, \& Syazali, M. (2017). Pengembangan Media Pembelajaran Matematika Dengan Macromedia Flash. Al-Jabar: Jurnal Pendidikan Matematika, 8(2), 177.

[24] Muhson, A. (2010). Pengembangan Media Pembelajaran Berbasis Teknologi Informasi. Jurnal Pendidikan Akuntansi Indonesia, 8(2), 1-10.

[25] Mulyadi. (2011). Android App Inventor Membuat Aplikasi Android Tanpa Kode Program. Yogyakarta: Multimedia Center Publishing.

[26]___(2017). Kiat Sukses Meraih Hibah Penelitian Pengembangan. Yogyakarta: Deepublish

[27] Mulyastuti, I. D. (2017). Pengembangan Media Pembelajaran Matematika Berbasis Geogebra Pada Materi Garis Singgung Lingkaran Untuk Siswa Kelas VIII SMP Negeri 1 Purwodadi. Skripsi. Surakarta: Fakultas Keguruan Dan Ilmu Pendidikan Universitas Muhammadiyah Surakarta

[28] Mulyawati, C., Salmawaty, Subianto, M., \& Wafdan, R. (2017). Teaching Media Development Of Mathematic In The Materials Trigonometry Sum And Two Angles Difference By Using Gui Matlab. Jurnal Natural, 17(2).

[29] Nurhayati. (2013). Pemberdayaan E-Learning Sebagai Media Pembelajaran Ramah Lingkungan. Jurnal Saintech, 05(01), 50-57.

[30] Plomp, T \& Nieveen, N. (2013). Educational Design Research: An Introduction (Eds). Netherlands: SLO

[31] Republik Indonesia. (2003). Undang-Undang Republik Indonesia Nomor 20 Tahun 2003 Tentang Sistem Pendidikan Nasional. Lembaran Negara Republik Indonesia Tahun 2003 Nomor 4301. Jakarta: Sekretariat Negara.

[32] Reza, M. F. A., \& Purwanti, D. (2017). Pengembangan Media Pembelajaran Dalam Bentuk Buku Saku Digital Berbasis Android Materi Ajar Gerak Dan Gaya Di SMK 1 Kedungwuni. Edu Komputika Journal, 4(2), 1-5.

[33] Risma. (2019). Pengembangan Android Mobile Learning Menggunakan MIT App Inventor Sebagai Media Pembelajaran Matematika Pada Materi Dasar-Dasar Logika. Skripsi. Lampung: Fakultas Tarbiyah dan Keguruan Universitas Negeri Raden Intan Lampung.

[34] Rufii, R. (2015). Developing Module On Constructivist Learning Strategies To Promote Students' Independence And Performance. International Journal Of Education, 7(1), 18.

[35] Rusgianto H.S. (2012). Trigonometri. Yogyakarta: CV. Grafika Indah.

[36] Rusman., dkk. (2012). Pembelajaran Berbasis Teknologi Informasi dan Komunikasi. Jakarta: Raja Grafindo Persada.

[37] Sadiman, Arief S. dkk. (2011). Media Pendidikan. Jakarta: Rajawali Pers.
[38] Salbino, S.(2014). Buku Pintas Gadget Android Untuk Pemula. Brebes: Kunci Komunikasi.

[39] Sari, F. K., Farida, \& M.Syazali. (2016). Pengembangan Media Pembelajaran (Modul) Berbantuan Geogebra Pokok Bahasan Turunan Fiska. Jurnal Pendidikan Matematika, 7(2), 135-152.

[40] Satyaputra, A., \& Aritonang, E. M. (2014). Beginning Android Programming With Adt Budle. Jakarta: Elex Media Komputindo.

[41] Siskawati, M., Pargito, \& Pujiati. (2016). Pengembangan Media Pembelajaran Monopoli Untuk Meningkatkan Minat Belajar Geografi Siswa. Jurnal Studi Sosial 4(1), 72-80.

[42] Smaldino, S.E., \& Russel, J.D. (2005). Instructional Technology and Media for Learning. Upper Saddle River: Pearson Educatiom, Inc.

[43] Sugiyono. (2013). Metode Penelitian Pendidikan Pendekatan Kuantitatif, Kualitatif, Dan R\&D. Bandung: Alfabeta.

[44] _ (2015). Metode Penelitian Kombinasi (Mix Methods). Bandung: Alfabeta.

[45] Sundayana, R. (2013). Media Pembelajaran Matematika (Untuk Guru, Calon Guru, Orang Tua, Dan Para Pecinta Matematika). Bandung: Alfabeta.

[46] Suprihatiningrum, J. (2012). Strategi Pembelajaran. Yogyakarta : A-Ruzz Media

[47] Wikipedia, Ensiklopedia Bebas. (2020). Daftar versi Android. Diakses pada 7 maret 2020, dari https://id.wikipedia.org/w/index.php?title=Daftar_versi_ Android\&oldid $=16627661$

[48] Wirawan, P. W. (2012). Pengembangan Kemampuan ELearning Berbasis Web Ke Dalam M-Learning. Jurnal Masyarakat Informatika, 2(4), 21-26.

[49] Yudanto, D., \& Wiyatmo, Y. (2017). Pengembangan Media Pembelajaran Mobile Learning Pada Platform Android Berbasis App Inventor Sebagai Sumber Belajar Mandiri Untuk Meningkatkan Hasil Belajar Fisika Siswa SMA N 8 Yogyakarta. Jurnal Pendidikan Fisika , 6(3), 190-196. 